\title{
Bentuk-Bentuk Fatherhood di Film Indonesia Era 2000-an
}

\author{
Sri Wijayanti \\ Prodi Ilmu Komunikasi Universitas Pembangunan Jaya \\ sri.wijayanti@upj.ac.id
}

\begin{abstract}
ABSTRAK
Tujuan penelitian adalah menguraikan Penggambaran bentuk-bentuk fatherhood di film Indonesia era 2000-an. Penelitian ini menarik dilakukan karena hasil survei menyatakan Indonesia merupakan negara ketiga di dunia sebagai negara tanpa ayah (fatherless country). Padahal ditengarai sejak awal abad ke-21, di Amerika Serikat muncul kecenderungan peningkatan keterlibatan laki-laki sebagai bagian integral kegiatan domestik, sekaligus peran dan tanggung jawab ayah dalam pengasuhan anak. Untuk itu, penelitian ini menganalisis 10 karakter ayah di film Indonesia produksi tahun 2000-2020. Metode penelitian menggunakan analisis isi untuk mengambarkan bentuk fatherhood mengunakan fathering indicator framework sebagai alat ukurnya. Temuan penelitian menunjukkan film Indonesia era 2000-an menggambarkan ayah sebagai sosok yang tidak hanya berperan sebagai pemberi nafkah, tetapi juga berperan sebagai supportive dan cooperative caregiver, role model yang baik, termasuk menjadi bagian integral urusan domestik. Pergeseran Penggambaran fatherhood dipengaruhi konteks sosio kultural dan trend sosial di dunia yang terkait dengan sistem patriarki.
\end{abstract}

Kata-kata Kunci: Fatherhood, film Indonesia, karakter, patriarki

\section{Fatherhood in the $21^{\text {st }}$ Century Indonesian Films}

\begin{abstract}
The purpose of this research is to describe the depiction of the forms of fatherhood in Indonesian films in the 2000s era. This research is interesting because the survey results state that Indonesia is the third country in the world as a fatherless country. Whereas it is suspected that since the beginning of the 21st century, in the United States there has been a tendency to increase the involvement of men as an integral part of domestic activities, as well as the role and responsibility of fathers in raising children. For this reason, this study analyze 10 father characters in Indonesian films produced in 2000-2020. The research method uses content analysis to describe the form of fatherhood using the fathering indicator framework as a measuring tool. Research findings show that Indonesian films in the 2000s depicted the father as a figure who not only played a role as a breadwinner, but also played a supportive and cooperative caregiver, a good role model, including being an integral part of domestic affairs. The shift in the depiction of fatherhood is influenced by the socio-cultural context and social trends in the world related to the patriarchal system.
\end{abstract}

Keywords: fatherhood, Indonesian films, character, patriarchy

\section{PENDAHULUAN}

\section{Hasil survei Fatherhood Institute's}

Fairness in Families Index menunjukkan bahwa

Indonesia menduduki peringkat ke-3 di dunia sebagai fatherless country (www.jpnn.com, 31

Maret 2021). Fatherless diartikan sebagai anak yang tumbuh kembangnya tanpa kehadiran ayah, atau anak yang mempunyai ayah tetapi ayahnya tidak berperan maksimal dalam proses tumbuh kembang (pengasuhan) anak. Artinya di Indonesia, 
Jurnal PIKMA: Publikasi Media Dan Cinema, Volume 4, No. 1, September 2021, hlm 56-71

ketidakhadiran seorang ayah baik secara fisik atau psikologis dalam kehidupan anak cukup besar.

Tingginya fenomena fatherless disebabkan peran gender tradisional (nilai patriarki) yang masih diyakini oleh masyarakat Indonesia. Reduksi peran gender tradisional memosisikan ibu sebagai penanggung jawan urusan domestik dan ayah sebagai penanggung jawab terkait nafkah masih melekat di masyarakat. Menurut Retno Listyarti, Komisioner Komisi Perlindungan Anak Indonesia (KPAI), menyatakan padahal tumbuh kembang anak sangat dipengaruhi oleh kehadiran dari kedua orang tuanya dalam pengasuhan (www.jpnn.com, 31 Maret 2021).

Sedang menurut Irwan Rinaldi, pakar komunikasi keluarga, kekosongan peran ayah dalam pengasuhan anak, terutama dalam periode usia 7-15 tahun memberikan pengaruh (www.kemenpppa.go.id, 10 September 2020). Hal tersebut terjadi karena anak kehilangan sosok ayah sebagai panutan dan pendamping hidup. Sejumlah dampak negatif akibat fatherless bagi anak-anak diantaranya, rasa kurang percaya diri, cenderung menarik diri dikehidupan sosial, rentan terlibat penyalahgunaan NAPZA, rentan melakukan tindak kriminal dan kekerasan, kondisi kesehatan mental yang bermasalah, munculnya depresi hingga gangguan masalah akademis disekolah.

Di Indonesia, penggambaran fatherless tampak dari fenomena yang terjadi di masyarakat seperti keluarga kaya yang kehilangan figur ayah karena sibuk bekerja dan sering bepergian, sehingga tanpa sadar tidak menjadikan keluarga sebagai prioritas. Atau sebuah keluarga miskin yang tidak memiliki figur ayah karena ibunya merupakan istri muda. Hal tersebut menunjukkan bahwa ibu masih tetap menjadi contoh pola asuh utama, sedangkan ayah masih memperlihatkan peran yang lebih banyak menjadi pencari nafkah.

Tidak dapat dipungkiri, memang konteks sosial dan sejarah mempengaruhi konsepsi populer dan ilmiah terkait anak, keluarga dan pengasuhan. Seperti halnya yang terjadi di Amerika Serikat yang mengalami pergeseran terkait konsep tradisional ayah menjadi konsep fatherhood, dimana ayah digambarkan menunjukkan rasa cinta, dukungan emosional, hadir bagi anak-anaknya, mengajarkan, membimbing dan menjadi pelatih bagi anak-anaknya.

Perubahan konsep peran ayah tersebut ditengarai dipengaruhi adanya empat trend sosial penting pada awal permulan abad ke-21, yang pada akhirnya membawa perubahan mendasar pada konteks sosial budaya dimana anak-anak berkembang. Empat trend sosial penting tersebut di antaranya: peningkatan partisipasi perempuan sebagai angkatan kerja, peningkatan ketidakhadiran ayah di rumah, peningkatan keterlibatan ayah dalam sebuah keluarga utuh dan peningkatan keragaman budaya di Amerika Serikat (Cabrera Natasha, Bradley, 2000).

Konsep fatherhood yang berkembang di Amerika Serikat sejak awal 2000-an tampak dari penggambaran karakter ayah di sejumlah film. Misalnya saja pada film “Daddy Day Care” (2003), “The Pursuit of Happiness" (2006), "Daddy Day Camp" (2007), “Delivery Man" (2013) hingga 24 judul film animasi Disney yang diproduksi 
Jurnal PIKMA: Publikasi Media Dan Cinema, Volume 4, No. 1, September 2021, hlm 56-71

sepanjang tahun 2000-2013. Beberapa diantaranya yang populer, misalnya "Finding Nemo" (2003),

“The Incredibles" (2004), “Ratatouille” (2007), "Brave” (2012), “Frozen” (2013).

Sebenarnya, apa yang digambarkan di film merupakan cerminan realitas yang ada di masyarakat tempat dimana film tersebut diproduksi. Film dipilih untuk digunakan sebagai media penyampai pesan fatherhood karena diyakini memiliki kekuatan persuasi pada penontonnya. Hasil penelitian dengan judul "The Portrayal of Men in The Media" menunjukkan bagaimana penggambaran ayah di film akan mempengaruhi bagaimana penonton menilai sosok ayah (Jove \& Ivy, 2010). Dalam hal ini film memiliki sejumlah fungsi, seperti fungsi informasi, transmisi budaya, pewarisan sosial, melawan kekuasaan dan kekuatan represif, dengan tentu saja fungsi hiburan sebagai porsi terbesar.

Sehingga kemudian penting dan menarik mengamati film-film Indonesia yang diproduksi antara tahun 2000-2020 dengan tema fatherhood melalui karakter ayah dengan relasinya terhadap anak-anak mereka. Paling tidak tercatat 10 film Indonesia yang menggambarkan ayah dalam kehidupan keluarga khususnya relasi dengan anak, seperti yang tampak pada tabel 1 .

Tabel 1. Film Indonesia Tema Fatherhood Produksi Tahun 2000-2020

\begin{tabular}{|c|l|l|c|c|l|}
\hline $\begin{array}{c}\text { N } \\
\text { o }\end{array}$ & Thn & Judul & Genre & $\begin{array}{c}\text { Duras } \\
\text { i }\end{array}$ & $\begin{array}{l}\text { Karakter } \\
\text { Ayah }\end{array}$ \\
\hline 1 & $\begin{array}{l}200 \\
7\end{array}$ & $\begin{array}{l}\text { Nagabonar } \\
\text { jadi 2 }\end{array}$ & $\begin{array}{l}\text { Drama } \\
\text { komedi }\end{array}$ & $124^{\prime}$ & $\begin{array}{l}\text { Nagabona } \\
\text { r }\end{array}$ \\
\hline 2 & $\begin{array}{l}201 \\
3\end{array}$ & $\begin{array}{l}\text { Tampan } \\
\text { Tailor }\end{array}$ & Drama & $104^{\prime}$ & Topan \\
\hline 3 & $\begin{array}{l}201 \\
1\end{array}$ & $\begin{array}{l}\text { Lovely } \\
\text { Man }\end{array}$ & Drama & $76^{\prime}$ & $\begin{array}{l}\text { Syaiful/ } \\
\text { Ipuy }\end{array}$ \\
\hline 4 & $\begin{array}{l}201 \\
5\end{array}$ & $\begin{array}{l}\text { Ayah } \\
\text { Menyayang }\end{array}$ & Drama & $88^{\prime}$ & Ar (juna) \\
\hline
\end{tabular}

\begin{tabular}{|c|c|c|c|c|c|}
\hline & & $\begin{array}{l}\text { i Tanpa } \\
\text { Akhir }\end{array}$ & & & \\
\hline 5 & $\begin{array}{l}201 \\
5\end{array}$ & $\begin{array}{l}\text { Mencari } \\
\text { hilal }\end{array}$ & Drama & $94^{\prime}$ & Mahmud \\
\hline 6 & $\begin{array}{l}201 \\
6\end{array}$ & $\begin{array}{l}\text { Sabtu } \\
\text { Bersama } \\
\text { Bapak }\end{array}$ & Drama & $100^{\prime}$ & Gunawan \\
\hline 7 & $\begin{array}{l}201 \\
6\end{array}$ & $\begin{array}{l}\text { Cek Toko } \\
\text { Sebelah }\end{array}$ & $\begin{array}{l}\text { Drama } \\
\text { Komed } \\
\mathrm{i}\end{array}$ & $104^{\prime}$ & Koh Afuk \\
\hline 8 & $\begin{array}{l}201 \\
9\end{array}$ & $\begin{array}{l}\text { Keluarga } \\
\text { Cemara }\end{array}$ & Drama & $110^{\prime}$ & Abah \\
\hline 9 & $\begin{array}{l}201 \\
9\end{array}$ & $\begin{array}{l}\text { Orang } \\
\text { Kaya Baru }\end{array}$ & $\begin{array}{l}\text { Drama } \\
\text { komedi }\end{array}$ & $96^{\prime}$ & HIkmat \\
\hline 10 & $\begin{array}{l}202 \\
0\end{array}$ & $\begin{array}{l}\text { Nanti Kita } \\
\text { Cerita } \\
\text { Tentang } \\
\text { Hari Ini }\end{array}$ & Drama & $120^{\prime}$ & Narendra \\
\hline
\end{tabular}

Sumber: Olahan peneliti (2021)

Secara garis besar, dari kesepuluh film Indonesia yang akan dijadikan unit analisis dalam penelitian ini, 8 judul film diantaranya, yakni "Naga Bonar jadi 2", “Tampan Tailor", "Lovely Man”, “Ayah Menyayangi Tanpa Akhir", "Mencari Hilal”, "Sabtu Bersama Bapak", “Cek Toko Sebelah", dan "Orang Kaya Baru" menggambarkan karakter ayah sebagai single parent, disebabkan karena pasangannya meninggal ataupun bercerai. Sementara 2 judul film lainnya, yakni "Keluarga Cemara" dan "Nanti Kita Cerita Tentang Hari” (NKCTH) ini menggambarkan karakter ayah dalam sebuah keluarga utuh.

Konsep fatherhood (kebapakan) secara sederhana diartikan sebagai keterlibatan ayah untuk lebih bertanggung jawab pada hal-hal yang terkait dengan mengasuh anak dan pekerjaan rumah tangga (Johanssan dalam Evans, 2015). Adapun elemen-elemen fatherhood menurut Nicholas Townsend meliputi : intimacy (kedekatam emosional dengan anak), provision (memungkinkan seorang pasangan mengasuh anak; menentukan standar materi bagi kehidupan 
Jurnal PIKMA: Publikasi Media Dan Cinema, Volume 4, No. 1, September 2021, hlm 56-71

keluarga), protection (perlindungan terhadap bahaya fisik ataupun pengaruh negatif) dan endowment (memberikan waktu, uang, dan tenaga untuk anak dan keluarga; membuat kesempatan positif untuk berolahraga, pembelajaran dan sekolah; mengajarkan karakter pada anak) (Townsend dalam Jensen, 2015).

Disamping konsep fatherhood, terdapat konsep fathering (keayahan) yang memiliki makna yang kurang lebih sama. Fathering adalah suatu peran ayah dalam kaitannya dengan tugas untuk mengarahkan anak-anak menjadi mandiri baik secara fisik maupun psikologis (Canfield dalam Hardianto, 2015). Ayah mempunyai peranan dan tanggung jawab yang penting bagi pertumbuhan dan kesehatan anak-anak. Peranan dan tanggung menjadi ayah (fathering) sudah terbangun semenjak laki-laki mempunyai keturunan.

Tercatat sejumlah penelitian pernah dilakukan sebelumnya terkait fatherhood. Pertama, penelitian yang dilakukan oleh Ercan Gurova dengan judul "Modern Fatherhood in Films" (2016) menemukan bahwa konsep fatherhood telah mengalami perubahan signifikan dalam hal peran dan partisipasi ayah dalam keluarga. Seiring dengan efek globalisasi di abad ke-21, peran ayah semakin "detradisionalisasi". Konsep ayah baru, memunculkan peran ayah lebih terlibat dalam kehidupan keluarga, memiliki kualitas lebih dalam hal aksesibilitas, keterlibatan yang bertanggung jawab serta peran gender dalam keluarga yang lebih berimbang.

Kedua, yang dilakukan oleh Cabrera etc (2020) dengan judul Fatherhood In The Twenty-
First Century menghasilkan temuan bahwa empat trend sosial secara mendasar telah mengubah konteks sosial budaya dimana anak-anak berkembang. Penelitian fatherhood kedepannya perlu mempertimbangkan konteks sosiohistoris dan struktur keluarga.

Ketiga, penelitian yang menghasilkan indikator fathering sebagai temuannya, dilakukan oleh Gadsden etc (2001) berjudul The Fathering Indicators Framework : A Tool for Quantitative and Qualitative Analysis. Adapun kategori indikator fathering yang dihasilkan meliputi : Father Presence (kehadiran ayah), Caregiving (pengasuhan), Children Social Competence and Academic Achievement (kompetensi sosial dan prestasi akademik bagi anak-anak), Cooperative Parenting (orang tua yang kooperatif), Father Healthy Living (gaya hidup sehat ayah), Material and Financial Contributions (kontribusi keuangan dan materi).

Keempat, studi Penggambaran ayah di media seperti televisi, buku, film yang dilakukan oleh National Fatherhood Inatiative (NFI) (2007), organisasi nirlaba yang bertujuan meningkatkan kesejahteraan anak-anak. Hasil studi mengungkapkan bahwa ayah ditampilkan dalam sisi negatif sebanyak 8 kali lebih banyak dibandingkan dengan ibu. Hal ini diperkuat oleh penelitian yang dilakukan oleh Adam, Walker dan Connell dengan judul "Representasi orang tua dalam Buku Bergambar Anak” (2011). Temuannya menunjukkan bahwa terdapat ketimpangan representasi antara ayah dan ibu, dimana ayah 
Jurnal PIKMA: Publikasi Media Dan Cinema, Volume 4, No. 1, September 2021, hlm 56-71

secara signifikan kurang terwakili dalam hal kontak fisik dengan anak-anak mereka.

Kelima, penelitian fathering yang mengambil obyek film Disney pernah dilakukan oleh Nikita Hardianto dengan judul "Analisis Isi Konten Fathering dalam Film Animasi Disney tahun 2000-2013" (2015). Hasilnya adalah karakter ayah yang digambarkan film animasi Disney memperlihatkan realitas gambaran "ayah baru" yang tidak hanya aktif di ruang publik dan memberi nafkah, namun ikut serta mendukung kegiatan domestik bersama ibu.

Keenam, dalam konteks Indonesia, penelitian yang pernah dilakukan berjudul "Representasi fatherhood dalam Majalah Ayahbunda" oleh Elly Manika (2016). Temuannya menyatakan bahwa ayah direpresentasikan secara supportif, sensitif, dan mengalami pergeseran makna maskulinitas. Meski ayah tetap digambarkan sebagai pencari nafkah utama, namun ayah juga ditampilkan sebagai sosok yang memberikan dukungan pada ibu dalam mengurus anak dan keperluan rumah tangga. Disamping itu, ayah ditampilkan sebagai sosok yang sensitif, ekspresif dan terbuka mengungkapkan perasaannya, termasuk hal-hal yang terkait dengan kedekatan emosional dalam relasi ayah dan anak.

Merujuk pada sejumlah hasil penelitian sebelumnya, penelitian ini menawarkan kebaruan dengan mencoba mengambarkan bentuk-bentuk fatherhood dalam karakter ayah di film Indonesia yang diproduksi antara tahun 2000-2020.

\section{METODOLOGI}

Metode penelitian yang digunakan dalam penelitian ini adalah analisis isi kualitatif deskriptif. Oleh karena penelitian ini hendak mengambarkan aspek dan dimensi pesan dari sebuah teks. Obyek penelitian ini adalah fatherhood yang ditampilkan dalam film Indonesia yang diproduksi antara tahun 2000-2020.

Adapun 10 film yang akan dijadikan unit analisis penelitian ini adalah Nagabonar jadi 2 (2007), Tampan Tailor (2013), Lovely Man (2011), Ayah Menyayangi Tanpa Akhir (2015), Mencari Hilal (2015), Sabtu Bersama Bapak (2016), Cek Toko Sebelah (2016), Keluarga Cemara (2019), Orang Kaya Baru (2019) dan Nanti Kita Cerita Tentang Hari Ini (2020).

Sejumlah pertimbangan pemilihan 10 film tersebut untuk dijadikan unit analisis adalah: pertama, tema yang diangkat di film terkait dengan fatherhood, yang ditampilkan melalui relasi antara karakter ayah dan anak. Kedua, film-film tersebut diproduksi pada era 2000-an sejalan dengan munculnya trend sosial dunia di awal abad ke-21 yang membawa perubahan mendasar terkait peran dan partisipasi ayah dalam pengasuhan anak. Ketiga, beragamnya konteks sosiokultural dalam relasi ayah-anak yang diangkat di film-film tersebut, mulai dari status ayah dalam struktur keluarga, pengaruh gender anak, orientasi seksual, etnis maupun agama. Secara teoritis keberagaman konteks sosio kultural mempengaruhi bentuk fatherhood.

Data penelitian ini dikumpulkan dengan mendokumentasikan Penggambaran fatherhood 
pada karakter Nagabonar, Topan, Syaiful, Juna, Mahmud, Gunawan, Koh Afuk, Abah, Hikmat dan Narendra sebagai sosok ayah dalam relasinya dengan anak mereka di film yang menjadi unit analisis.

Selanjutnya data yang telah terkumpul akan dianalisis dengan menggunakan Fathering Indicator Framework dari Gadsden etc (2001). Berikutnya, hasil analisis data akan diinterpretasikan menggunakan konsep fatherhood, konsep film sebagai media representasi realitas serta konsep terkait gender role dalam budaya patriarki.

\section{HASIL DAN PEMBAHASAN}

Temuan dan diskusi hasil penelitian ini akan diuraikan kedalam tiga bagian. Konteks relasi ayah dan anak, bentuk fatherhood relasi ayah-anak dan fatherhood film Indonesia era 2000-an.

\section{Konteks Relasi Ayah dan Anak}

Pada bagian ini akan diuraikan konteks relasi yang terjadi antara karakter ayah dan anak di masing-masing film. Secara teoritis, konteks sosio kultural akan mempengaruhi bentuk pengasuhan. Untuk mempermudah pembacaan, data hasil temuan akan dibuat dalam bentuk tabel.

Tabel 2. Konteks dalam Relasi Ayah-Anak

\begin{tabular}{|c|l|l|l|}
\hline No & \multicolumn{1}{|c|}{ Film } & $\begin{array}{c}\text { Relasi } \\
\text { Ayah- } \\
\text { Anak }\end{array}$ & \multicolumn{1}{|c|}{ Konteks } \\
\hline 1 & $\begin{array}{l}\text { Nagabonar } \\
\text { jadi } 2\end{array}$ & $\begin{array}{l}\text { Nagabonar- } \\
\text { Bonaga }\end{array}$ & $\begin{array}{l}\text { Single parent, } \\
\text { etnis Batak, } \\
\text { ayah-anak laki- } \\
\text { laki }\end{array}$ \\
\hline 2 & $\begin{array}{l}\text { Tampan } \\
\text { Tailor }\end{array}$ & $\begin{array}{l}\text { Topan- } \\
\text { Bintang }\end{array}$ & $\begin{array}{l}\text { Single parent, } \\
\text { ayah-anak laki- } \\
\text { laki }\end{array}$ \\
\hline
\end{tabular}

\begin{tabular}{|c|l|l|l|}
\hline 3 & Lovely Man & $\begin{array}{l}\text { Syaiful- } \\
\text { Cahaya }\end{array}$ & $\begin{array}{l}\text { Single parent, } \\
\text { ayah-anak } \\
\text { perempuan, } \\
\text { transgender }\end{array}$ \\
\hline 4 & $\begin{array}{l}\text { Ayah } \\
\text { Menyayangi } \\
\text { Tanpa Akhir }\end{array}$ & $\begin{array}{l}\text { Ar (juna)- } \\
\text { Mada }\end{array}$ & $\begin{array}{l}\text { Single parent, } \\
\text { etnis Jawa } \\
\text { (Solo), ayah-anak } \\
\text { laki-laki }\end{array}$ \\
\hline 5 & $\begin{array}{l}\text { Mencari } \\
\text { hilal }\end{array}$ & $\begin{array}{l}\text { Mahmud- } \\
\text { Helli }\end{array}$ & $\begin{array}{l}\text { Single parent, } \\
\text { agama (Islam), } \\
\text { ayah-anak laki- } \\
\text { laki }\end{array}$ \\
\hline 6 & $\begin{array}{l}\text { Sabtu } \\
\text { Bersama } \\
\text { Bapak }\end{array}$ & $\begin{array}{l}\text { Gunawan- } \\
\text { Satya \& } \\
\text { Cakra }\end{array}$ & $\begin{array}{l}\text { Single parent, } \\
\text { ayah-anak laki- } \\
\text { laki }\end{array}$ \\
\hline 7 & $\begin{array}{l}\text { Cek Toko } \\
\text { Sebelah }\end{array}$ & $\begin{array}{l}\text { Koh Afuk- } \\
\text { Yohan \& } \\
\text { Erwin }\end{array}$ & $\begin{array}{l}\text { Single parent, } \\
\text { etnis Tionghoa, } \\
\text { ayah-anak laki- } \\
\text { laki }\end{array}$ \\
\hline 8 & $\begin{array}{l}\text { Keluarga } \\
\text { Cemara }\end{array}$ & $\begin{array}{l}\text { Abah-Euis } \\
\text { \& Ara }\end{array}$ & $\begin{array}{l}\text { Keluarga utuh, } \\
\text { ayah-anak } \\
\text { perempuan }\end{array}$ \\
\hline 9 & $\begin{array}{l}\text { Orang Kaya } \\
\text { Baru }\end{array}$ & $\begin{array}{l}\text { Hikmat- } \\
\text { Duta, Tika } \\
\text { dan Dodi }\end{array}$ & $\begin{array}{l}\text { Single parent, } \\
\text { ayah-anak laki- } \\
\text { laki dan anak } \\
\text { perempuan }\end{array}$ \\
\hline 10 & $\begin{array}{l}\text { Nanti Kita } \\
\text { Cerita } \\
\text { Tentang } \\
\text { Hari Ini }\end{array}$ & $\begin{array}{l}\text { Narendra- } \\
\text { Angkasa, } \\
\text { Aurora dan } \\
\text { Awan }\end{array}$ & $\begin{array}{l}\text { Keluarga utuh, } \\
\text { ayah-anak laki- } \\
\text { laki dan anak } \\
\text { perempuan }\end{array}$ \\
\hline
\end{tabular}

Sumber : Olahan peneliti (2021)

Di film "Nagabonar jadi 2" (2007), karakter Nagabonar sebagai ayah single parent dari seorang anak laki-laki (Bonaga) yang sudah dewasa digambarkan mengalami perbenturan nilai-nilai moral yang dimilikinya dengan nilai yang berlaku saat ini sebagaimana yang dianut anaknya. Dengan latar belakang etnis Batak, Nagabonar merawat anaknya sejak lahir dengan nilai dan kebiasaan yang dimilikinya secara turun menurun.

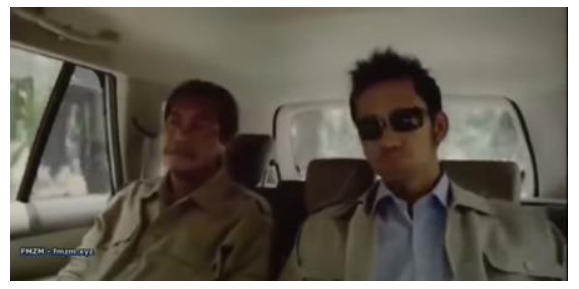

Gambar 1. Nagabonar dan Bonaga Sumber: capture film "Nagabonar jadi-2" 
Seperti halnya Nagabonar, Topan di film “Tampan Tailor" (2013) menjadi single parent dari seorang anak lak-laki bernama Bintang, setelah kehilangan istri dan usaha toko jahitnya. Perjuangan Topan untuk menyambung hidup dengan mencoba berbagai pekerjaan sekaligus merawat Bintang digambarkan di sepanjang film ini.

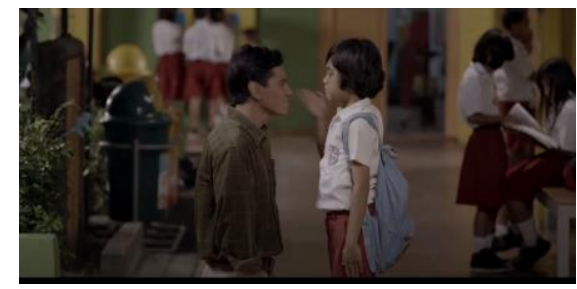

Gambar 2. Topan dan Bintang

Sumber: capture film "Tampan Tailor”

Karakter ayah yang berikutnya, digambarkan melalui tokoh Syaiful (Ipuy), seorang transgender yang secara biologis merupakan ayah dari gadis remaja yang bernama Cahaya di film "Lovely Man" (2011). Kompleksitas fatherhood karakter ayah yang digambarkan melalui film ini ditunjukkan melalui kondisi ayah yang seorang transgender dan bertemu dengan anaknya yang sudah menginjak usia remaja dengan berlatar belakang pendidikan pesantren dan sedang hamil hasil hubungan dengan pacarnya.

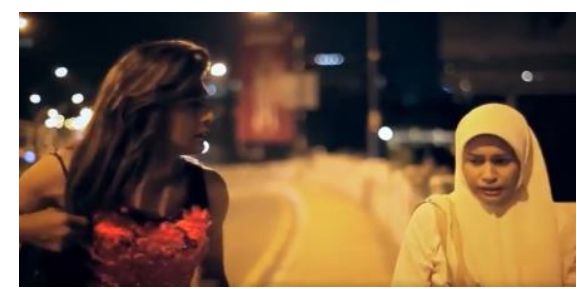

Gambar 3. Syaiful/Ipuy dan Cahaya

Sumber: film "Lovely Man”

Berikutnya, pada film “Ayah Menyayangi Tanpa Akhir" (2015), karakter Ar(Juna) merupakan ayah single parent setelah istrinya meninggal karena melahirkan Mada anak mereka. Praktis, semenjak itu, Ar(Juna) menjadi single parent untuk Mada anaknya, yang dikemudian hari ternyata mengidap penyakit mematikan. Penggambaran karakter ayah dalam film ini, ditunjukkan melalui upaya $\operatorname{Ar}(J u n a)$ merawat dan mengupayakan kesembuhan anaknya. Ar(Juna) sendiri merupakan keturunan bangsawan Surakarta yang rela 'diasingkan' keluarganya karena memilih menikah dengan gadis Jepang pilihannya. Akibatnya, Mada anaknya tidak diakui oleh keluarga kedua belah pihak, baik keluarga ibunya maupun keluarga ayahnya.

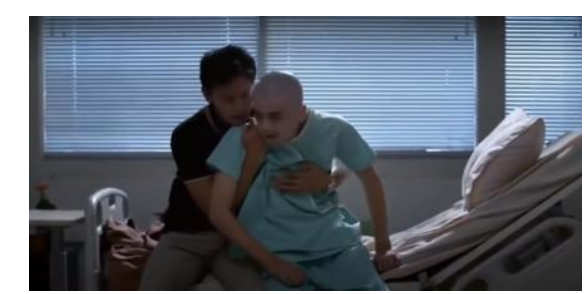

Gambar 4. Ar (Juna) dan Mada

Sumber: film "Ayah Menyayangi Tanpa Akhir"

Pada film selanjutnya yang berjudul "Mencari Hilal" (2015), ayah digambarkan melalui karakter Mahmud, single parent yang memiliki latar belakang keagamaan yang kuat dan selama ini berjuang menerapkan perintah agamanya dalam semua aspek kehidupannya. Dalam film ini, Penggambaran ayah melalui Mahmud difokuskan pada relasinya dengan anak bungsunya yang bernama Heli. Selama ini relasi mereka buruk akibat pertentangan nilai yang dianut masingmasing. Anaknya, merupakan seorang sekuler liberal yang menurut Mahmud merupakan kelompok sesat. 


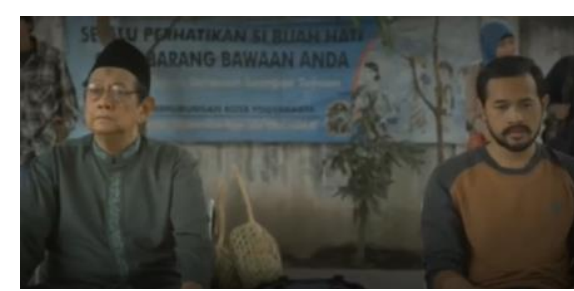

Gambar 5. Mahmud dan Helli

Sumber: film "Mencari Hilal"

Berbeda dengan karakter ayah dalam film "Mencari Hilal", penggambaran ayah dalam film "Sabtu Bersama Bapak" (2016) melalui karakter Gunawan ditampilkan cukup menarik. Dikarenakan dalam film ini, fatherhood dilakukan oleh ayah melalui rekaman video berisi pesanpesan terkait kehidupan untuk kedua anak lakilakinya, Satya dan Cakra, yang diputar setiap Sabtu perminggunya.

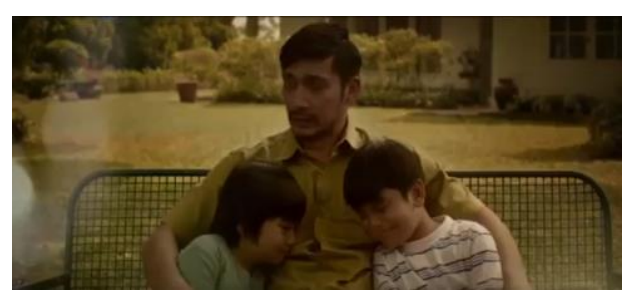

Gambar 6. Gunawan dan Satya-Cakra Sumber: film "Sabtu Bersama Bapak"

Dua film berikutnya merupakan film dengan genre komedi, yakni film "Cek Toko Sebelah" (2016) dan film "Orang Kaya Baru" (2019). Keduanya juga mengambarkan fatherhood melalui karakter Koh Afuk dan Hikmat. Koh Afuk sebagai ayah dalam film "Cek Toko Sebelah" digambarkan menjadi single parent setelah istrinya meningal. Mengambil realitas etnis Tionghoa di masyarakat, fatherhood ditampilkan oleh karakter Koh Afuk dalam relasinya dengan kedua anak lakilakinya yang sudah berusia dewasa.

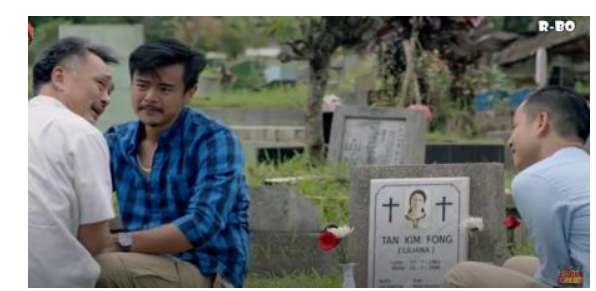

Gambar 7. Koh Afuk dan Yohan-Erwin Sumber: film "Cek Toko Sebelah"

Sebaliknya, dalam film "Orang Kaya Baru", karakter Hikmat sebagai ayah ditampilkan melalui warisan harta berlimpah yang diberikan pada keluarganya, istri dan ketiga anaknya yang selama ini menjalani kehidupan secara sangat sederhana.

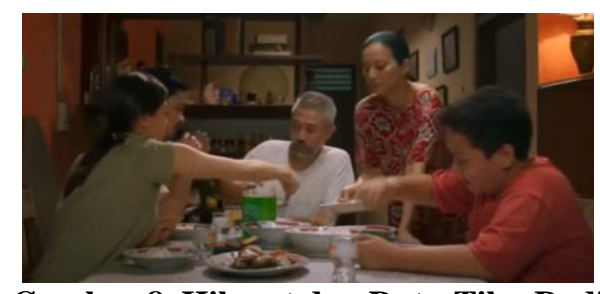

Gambar 8. Hikmat dan Duta-Tika-Dodi Sumber: film“Orang Kaya Baru"

Bila ke-8 film sebelumnya mengambarkan karakter ayah sebagai single parent, maka sebaliknya dalam dua film berikut ini, karakter ayah ditampilkan dalam keluarga yang utuh. Karakter Abah dalam film "Keluarga Cemara" (2019) dan Narendra dalam film Nanti Kita Cerita Tentang Hari Ini (NKCTHI) (2020). Pada film "Keluarga Cemara", karakter Abah digambarkan sebagai ayah yang harus berjuang mempertahankan prinsip harta yang paling berharga adalah keluarga, setelah bangkrut dan jatuh miskin secara ekonomi.

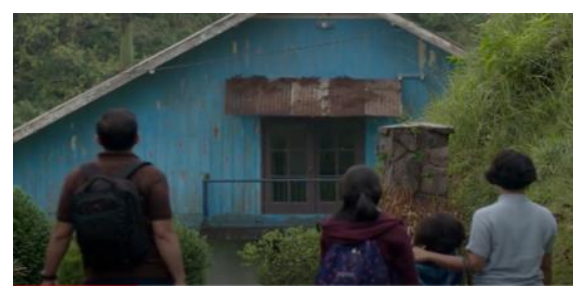

Gambar 9. Abah dan Euis-Ara Sumber: film "Keluarga Cemara" 
Sedangkan karakter Narendra sebagai ayah dalam film "Nanti Kita Cerita Tentang Hari Ini”(NKCTHI) ditampilkan cukup menarik dengan latar belakang adanya rahasia dan trauma besar dalam keluarga. Hal ini menyebabkan relasi antara ayah dan ketiga anaknya berjalan dengan tidak harmonis sehingga menyebabkan pemberontakan dari ketiga anaknya.

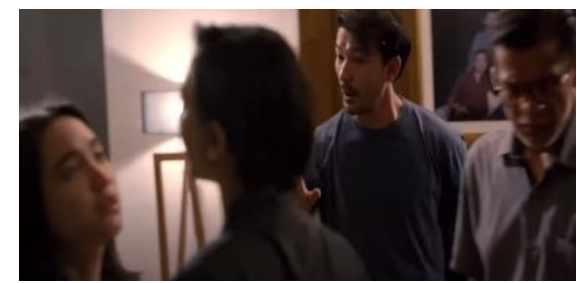

Gambar 10. Narendra dan Angkasa-Aurora-Awan Sumber: film "Nanti Kita Cerita Tentang Hari Ini”

\section{Bentuk fatherhood dalam Relasi Ayah-Anak}

Bagian ini akan menjelaskan Penggambaran fatherhood yang ditampilkan dalam setiap relasi ayah-anak sesuai dengan indikator kerangka fathering yang digunakan penelitian ini. Temuan penelitian menunjukkan bahwa karakter ayah di film Indonesia menjalankan sejumlah bentuk fatherhood.

Tabel 3 berikut menjelaskan bentuk father presence karakter ayah dalam relasi dengan anaknya. Father presence memiliki arti ayah hadir baik secara fisik maupun psikologis dalam kehidupan anaknya.

Tabel 3. Bentuk Father Presence di Film Indonesia berdasarkan Fathering Indicator Framework

\begin{tabular}{|c|l|l|}
\hline No & Judul Film & \multicolumn{1}{|c|}{ Father Presence } \\
\hline 1 & $\begin{array}{l}\text { Nagabonar } \\
\text { jadi dua }\end{array}$ & $\begin{array}{l}\text { Karakter Nagabonar mengasuh } \\
\text { Bonaga sejak dilahirkan } \\
\text { sampai dewasa, karena istrinya } \\
\text { meninggal saat melahirkan. }\end{array}$ \\
\hline 2 & $\begin{array}{l}\text { Tampan } \\
\text { Tailor }\end{array}$ & $\begin{array}{l}\text { Topan menjadi single parent } \\
\text { bagi Bintang semenjak Tami } \\
\text { meninggal saat Bintang masih } \\
\text { berusia sekolah dasar. }\end{array}$ \\
\hline
\end{tabular}

\begin{tabular}{|c|c|c|}
\hline 3 & Lovely man & $\begin{array}{l}\text { Karakter Ipuy meninggalkan } \\
\text { keluarganya sejak Cahaya, } \\
\text { anaknya berusia } 4 \text { tahun. } \\
\text { Bertemu kembali setelah } \\
\text { Cahaya berusia dewasa. Praktis } \\
\text { sepanjang waktu tersebut, } \\
\text { Cahaya tidak merasakan } \\
\text { kehadiran ayahnya. }\end{array}$ \\
\hline 4 & $\begin{array}{l}\text { Ayah } \\
\text { menyayangi } \\
\text { tanpa akhir }\end{array}$ & $\begin{array}{l}\text { Arjuna sebagai ayah menjadi } \\
\text { single parent bagi Mada, } \\
\text { semenjak istrinya meninggal } \\
\text { sesaat setelah melahirkan. } \\
\text { Bahkan menemani Mada } \\
\text { sampai meninggal karena sakit. }\end{array}$ \\
\hline 5 & $\begin{array}{l}\text { Mencari } \\
\text { hilal }\end{array}$ & $\begin{array}{l}\text { Meski berbeda pandangan, } \\
\text { karakter Mahmud senantiasa } \\
\text { ada bagi Helli anaknya. Bahkan } \\
\text { sampai Mahmud meninggal } \\
\text { dunia saat mencari hilal } \\
\text { bersama Helli. }\end{array}$ \\
\hline 6 & $\begin{array}{l}\text { Sabtu } \\
\text { bersama } \\
\text { Bapak }\end{array}$ & $\begin{array}{l}\text { Karakter Gunawan sebagai } \\
\text { ayah dikisahkan meninggal } \\
\text { dunia saat kedua anaknya } \\
\text { masih kecil karena sakit kanker } \\
\text { otak. Meski tidak hadir secara } \\
\text { fisik, kehadiran ayah } \\
\text { tergantikan dengan video } \\
\text { rekamannya berisi pesan yang } \\
\text { mereka tonton setiap Sabtu. }\end{array}$ \\
\hline 7 & $\begin{array}{l}\text { Cek toko } \\
\text { sebelah }\end{array}$ & $\begin{array}{l}\text { Karakter Koh Afuk menjadi } \\
\text { single parent semenjak istrinya } \\
\text { meninggal saat kedua anaknya } \\
\text { beranjak remaja.Praktis sejak } \\
\text { saat itu Koh Afuk menjadi ayah } \\
\text { sekaligus ibu bagi kedua anak } \\
\text { laki-lakinya. }\end{array}$ \\
\hline 8 & $\begin{array}{l}\text { Keluarga } \\
\text { Cemara }\end{array}$ & $\begin{array}{l}\text { Kehadiran Abah bagi kedua } \\
\text { anak perempuannya, Euis dan } \\
\text { Ara, justru semakin intensif } \\
\text { setelah mereka sekeluarga } \\
\text { pindah ke desa karena } \\
\text { mengalami kesulitan ekonomi. }\end{array}$ \\
\hline 9 & $\begin{array}{l}\text { Orang kaya } \\
\text { baru }\end{array}$ & $\begin{array}{l}\text { Karakter Hikmat sebagai ayah } \\
\text { dari tiga orang anak yang sudah } \\
\text { besar, diceritakan meninggal } \\
\text { secara mendadak setelah } \\
\text { makan malam bersama } \\
\text { keluarga. Meninggalnya ayah } \\
\text { menyebabkan kehilangan } \\
\text { momen kebersamaan yang } \\
\text { biasanya mereka lakukan saat } \\
\text { makan. }\end{array}$ \\
\hline 10 & $\begin{array}{l}\text { Nanti kita } \\
\text { cerita }\end{array}$ & $\begin{array}{l}\text { Karakter Narendra sebagai } \\
\text { ayah bagi ketiga anaknya } \\
\text { secara fisik senantiasa ada }\end{array}$ \\
\hline
\end{tabular}




\begin{tabular}{|l|l|l|}
\hline tentang hari & $\begin{array}{l}\text { dalam setiap kegiatan mereka, } \\
\text { mulai sejak kecil hingga } \\
\text { dewasa. }\end{array}$ \\
\hline
\end{tabular}

Sumber: hasil penelitian 2021

Dari sepuluh karakter ayah, tujuh diantaranya memenuhi peran father presence dalam relasi ayah-anak. Hanya karakter ayah di film Lovely man, Sabtu bersama bapak dan Orang kaya baru yang ditampilkan tidak hadir dalam kehidupan anak mereka.

Selanjutnya bentuk fatherhood sebagai material and financial contribution (pemberi nafkah). Kesepuluh karakter ayah di film dalam penelitian ini melakukan perannya sebagai provider ekonomi bagi anak dan keluarga mereka. Hal ini sesuai dengan peran gender tradisional yang memosisikan ayah sebagai penanggung jawab terkait nafkah. Tabel 4. Bentuk Material and financial contribution
di Film Indonesia berdasarkan Fathering Indicator Framework

\begin{tabular}{|c|c|c|}
\hline No & Judul Film & $\begin{array}{c}\text { Material and financial } \\
\text { contribution }\end{array}$ \\
\hline 1 & $\begin{array}{l}\text { Nagabonar } \\
\text { jadi dua }\end{array}$ & $\begin{array}{l}\text { Nagabonar memiliki usaha } \\
\text { perkebunan kelapa sawit, } \\
\text { sehingga secara materi, ia bisa } \\
\text { memberikan kehidupan yang } \\
\text { layak bahkan menyekolahkan } \\
\text { anaknya sampai S2 di luar } \\
\text { negeri. }\end{array}$ \\
\hline 2 & $\begin{array}{l}\text { Tampan } \\
\text { Tailor }\end{array}$ & $\begin{array}{l}\text { Karakter Topan harus berganti- } \\
\text { ganti pekerjaan setelah usaha } \\
\text { konveksinya bangkrut, mulai } \\
\text { dari menjadi calo tiket, buruh } \\
\text { bangunan, sampai menjadi } \\
\text { stuntman, sebelum akhirnya } \\
\text { kembali menjadi penjahit jas. }\end{array}$ \\
\hline 3 & Lovely man & $\begin{array}{l}\text { Ipuy yang seorang transgender } \\
\text { bekerja sebagai pekerja seks } \\
\text { komersil untuk membiayai } \\
\text { sekolah dan hidup anaknya di } \\
\text { kampung. }\end{array}$ \\
\hline 4 & $\begin{array}{l}\text { Ayah } \\
\text { menyayangi } \\
\text { tanpa akhir }\end{array}$ & $\begin{array}{l}\text { Juna adalah seorang apoteker } \\
\text { dan memiliki usaha apotek }\end{array}$ \\
\hline
\end{tabular}

\begin{tabular}{|c|c|c|}
\hline & & $\begin{array}{l}\text { sendiri, untuk membiayai Mada } \\
\text { yang sakit kanker otak. }\end{array}$ \\
\hline 5 & $\begin{array}{l}\text { Mencari } \\
\text { hilal }\end{array}$ & $\begin{array}{l}\text { Mahmud membiayai anak dan } \\
\text { keluarganya dengan memiliki } \\
\text { kios di pasar yang menjual } \\
\text { sembako. }\end{array}$ \\
\hline 6 & $\begin{array}{l}\text { Sabtu } \\
\text { bersama } \\
\text { Bapak }\end{array}$ & $\begin{array}{l}\text { Gunawan memberikan modal } \\
\text { untuk istrinya mendirikan } \\
\text { restaurant sebelum ia } \\
\text { meninggal dunia. }\end{array}$ \\
\hline 7 & $\begin{array}{l}\text { Cek toko } \\
\text { sebelah }\end{array}$ & $\begin{array}{l}\text { Koh Afuk memiliki toko } \\
\text { kelontong yang dirintis } \\
\text { bersama istrinya untuk } \\
\text { membiayai kehidupan dan } \\
\text { kebutuhan keluarga sehari-hari. }\end{array}$ \\
\hline 8 & $\begin{array}{l}\text { Keluarga } \\
\text { Cemara }\end{array}$ & $\begin{array}{l}\text { Karakter Abah yang } \\
\text { sebelumnya seorang pengusaha } \\
\text { properti yang sukses, bangkrut } \\
\text { karena ditipu, akhirnya menjadi } \\
\text { driver ojek online, setelah } \\
\text { sebelumnya sempat menjadi } \\
\text { buruh bangunan. }\end{array}$ \\
\hline 9 & $\begin{array}{l}\text { Orang kaya } \\
\text { baru }\end{array}$ & $\begin{array}{l}\text { Hikmat diceritakan merupakan } \\
\text { pengusaha yang kaya raya, } \\
\text { namun menyamar menjadi } \\
\text { orang sederhana. }\end{array}$ \\
\hline 10 & $\begin{array}{l}\text { Nanti kita } \\
\text { cerita tentang } \\
\text { hari ini }\end{array}$ & $\begin{array}{l}\text { Narendra merupakan seorang } \\
\text { developer properti yang sukses, } \\
\text { dan memiliki pengaruh yang besar } \\
\text { di kalangan pengusaha yang } \\
\text { bergerak dibidang arsitektur. }\end{array}$ \\
\hline
\end{tabular}

Sumber: hasil penelitian 2021

Terkait pemenuhan ekonomi, karakter ayah ditampilkan semuanya berperan sebagai pemberi nafkah. Bentuk fatherhood berikutnya yang ditampilkan dalam film Indonesia terkait dengan peran caregiving. Pengertian caregiving yakni keterlibatan ayah secara sadar dalam pengasuhan anak dan melindungi dari bahaya secara psikologis dan emosional. Temuan ini disajikan pada tabel 5 berikut ini:

Tabel 5. Bentuk Caregiving di Film Indonesia berdasarkan Fathering Indicator Framework

\begin{tabular}{|c|l|l|}
\hline No & Judul Film & \multicolumn{1}{|c|}{ Caregiving } \\
\hline 1 & $\begin{array}{l}\text { Nagabonar } \\
\text { jadi dua }\end{array}$ & $\begin{array}{l}\text { Nagabonar membelai rambut } \\
\text { Bonaga saat mau tidur, teringat } \\
\text { akan kebiasaannya sewaktu } \\
\text { menidurkan anaknya sewaktu } \\
\text { kecil. }\end{array}$ \\
\hline
\end{tabular}




\begin{tabular}{|c|c|c|}
\hline 2 & $\begin{array}{l}\text { Tampan } \\
\text { Tailor }\end{array}$ & $\begin{array}{l}\text { Topan menyuapi Bintang saat } \\
\text { makan untuk menunjukkan } \\
\text { perhatiannya. }\end{array}$ \\
\hline 3 & Lovely man & $\begin{array}{l}\text { Ipuy mendekap Cahaya yang } \\
\text { menanggis saat menceritakan } \\
\text { rasanya kehilangan ayah } \\
\text { selama ini. }\end{array}$ \\
\hline 4 & $\begin{array}{l}\text { Ayah } \\
\text { menyayangi } \\
\text { tanpa akhir }\end{array}$ & $\begin{array}{l}\text { Juna merawat Mada sejak kecil, } \\
\text { bahkan semakin intensif setelah } \\
\text { Mada dinyatakan sakit kanker } \\
\text { otak dan melakukan operasi. }\end{array}$ \\
\hline 5 & $\begin{array}{l}\text { Mencari } \\
\text { hilal }\end{array}$ & $\begin{array}{l}\text { Mahmud bersikap kaku ketika } \\
\text { menghadapi anaknya, terutama } \\
\text { terhadap Helli anak lelakinya. } \\
\text { Hal ini tampak dari jarak yang } \\
\text { senantiasa ada dalam relasi } \\
\text { keduanya. }\end{array}$ \\
\hline 6 & $\begin{array}{l}\text { Sabtu } \\
\text { bersama } \\
\text { Bapak }\end{array}$ & $\begin{array}{l}\text { Gunawan memberikan } \\
\text { perhatian ke Satya dan Cakra } \\
\text { melalui video pesan yang } \\
\text { diputar setiap Sabtu. }\end{array}$ \\
\hline 7 & $\begin{array}{l}\text { Cek } \\
\text { sebe }\end{array}$ & $\begin{array}{l}\text { Koh Afuk memang tidak } \\
\text { memperlihatkan } \\
\text { emosional dihadapan kedua } \\
\text { anak laki-lakinya. Meski } \\
\text { sebenarnya sebagai ayah, dia } \\
\text { memperhatikan masalah yang } \\
\text { dihadapi kedua anaknya. }\end{array}$ \\
\hline 8 & $\begin{array}{l}\text { Keluarga } \\
\text { Cemara }\end{array}$ & $\begin{array}{l}\text { Abah mendengarkan keluhan } \\
\text { Euis ketika mesti beradaptasi } \\
\text { dengan kehidupan sekolah } \\
\text { yang baru di desa. }\end{array}$ \\
\hline 9 & $\begin{array}{l}\text { Orang kaya } \\
\text { baru }\end{array}$ & $\begin{array}{l}\text { Hikmat mendengarkan keluhan } \\
\text { Tika tentang kehidupan } \\
\text { sederhana yang mereka rasakan } \\
\text { saat ini. }\end{array}$ \\
\hline 10 & $\begin{array}{l}\text { Nanti kita } \\
\text { cerita } \\
\text { tentang hari } \\
\text { ini }\end{array}$ & $\begin{array}{lcr}\text { Narendra yang selalu } \\
\text { membantu } & \text { menyelesaikan } \\
\text { tugas anak } & \text { kesayangannya } \\
\text { Awan. } & \\
\end{array}$ \\
\hline
\end{tabular}

Sumber: hasil penelitian 2021

Caregiving yang dilakukan ayah dalam sejumlah film di penelitian ini menggambarkan ayah sebagai sosok yang sensitif serta memiliki hubungan yang lebih emosional dengan anak mereka. Perhatian ayah diberikan secara fisik, verbal maupun perlakuan terhadap anak.

Children social competence and academic achievement merupakan bentuk fatherhood yang ditampilkan melalui karakter ayah dalam relasinya dengan anaknya dalam penelitian ini. Peran ayah sebagai children social competence and academic achievement ditampilkan pada hampir keseluruhan film dalam penelitian ini. Temuan pada bentuk children social competence and academic achievement disajikan pada tabel 6 berikut ini.

\begin{tabular}{|c|c|c|}
\hline No & Judul Film & $\begin{array}{l}\text { Children social competence } \\
\text { and academic achievement }\end{array}$ \\
\hline 1 & $\begin{array}{l}\text { Nagabonar } \\
\text { jadi dua }\end{array}$ & $\begin{array}{l}\text { Nagabonar } \text { berhasil } \\
\text { menyekolahkan Bonaga hingga } \\
\text { lulus S2 di luar negeri dan } \\
\text { menjadi pengusaha di bidang } \\
\text { properti. }\end{array}$ \\
\hline 2 & $\begin{array}{l}\text { Tampan } \\
\text { Tailor }\end{array}$ & $\begin{array}{l}\text { Topan dengan segenap tenaga } \\
\text { berusaha agar Bintang tidak } \\
\text { putus sekolah sesuai dengan } \\
\text { janjinya pada Tami } \\
\text { almarhumah istrinya. }\end{array}$ \\
\hline 3 & Lovely man & $\begin{array}{l}\text { Ipuy meski meninggalkan } \\
\text { anaknya, tetap mengirimkan } \\
\text { uang untuk keperluan hidup } \\
\text { dan sekolah anaknya setiap } \\
\text { bulannya } \\
\text { ditinggalkannya saat usia } 4 \\
\text { tahun. }\end{array}$ \\
\hline 4 & $\begin{array}{l}\text { Ayah } \\
\text { menyayangi } \\
\text { tanpa akhir }\end{array}$ & $\begin{array}{l}\text { Juna memilihkan sekolah yang } \\
\text { terbaik buat Mada, sesuai } \\
\text { dengan janjinya pada Keisha } \\
\text { almarhumah istrinya untuk } \\
\text { memberikan yang terbaik pada } \\
\text { anak mereka. }\end{array}$ \\
\hline 5 & $\begin{array}{l}\text { Mencari } \\
\text { hilal }\end{array}$ & $\begin{array}{l}\text { Mahmud berhasil mendidik } \\
\text { anaknya, Halida hingga bisa } \\
\text { memiliki pekerjaan di kantor } \\
\text { imigrasi, sementara Heli } \\
\text { menjadi aktivis lingkungan } \\
\text { yang vokal. }\end{array}$ \\
\hline 6 & $\begin{array}{l}\text { Sabtu } \\
\text { bersama } \\
\text { Bapak }\end{array}$ & $\begin{array}{l}\text { Gunawan melalui pesan video } \\
\text { yang ditonton kedua anaknya } \\
\text { dari kecil hingga dewasa, } \\
\text { berhasil mendidik anaknya } \\
\text { hingga memiliki prestasi baik } \\
\text { akademik maupun non } \\
\text { akademik. }\end{array}$ \\
\hline 7 & $\begin{array}{l}\text { Cek toko } \\
\text { sebelah }\end{array}$ & $\begin{array}{l}\text { Secara prestasi akademik, } \\
\text { kedua anaknya, terutama Erwin } \\
\text { cukup membanggakan. Namun }\end{array}$ \\
\hline
\end{tabular}




\begin{tabular}{|c|l|l|}
\hline & & $\begin{array}{l}\text { karakter Koh Afuk sebagai } \\
\text { ayah merasa sangat bangga } \\
\text { manakala ada yang bersedia } \\
\text { meneruskan usaha toko yang } \\
\text { dirintisnya. }\end{array}$ \\
\hline 8 & $\begin{array}{l}\text { Keluarga } \\
\text { Cemara }\end{array}$ & $\begin{array}{l}\text { Abah berusaha keras agar Euis } \\
\text { tetap bersekolah, meski } \\
\text { kehidupan mereka terpuruk } \\
\text { secara ekonomi. }\end{array}$ \\
\hline 9 & $\begin{array}{l}\text { Orang kaya } \\
\text { baru }\end{array}$ & $\begin{array}{l}\text { Hikmat selalu memilihkan } \\
\text { sekolah dengan kualitas terbaik } \\
\text { untuk ketiga anaknya, meski } \\
\text { kehidupan keseharian mereka } \\
\text { sederhana. }\end{array}$ \\
\hline 10 & $\begin{array}{l}\text { Nanti kita } \\
\text { cerita } \\
\text { tentang hari } \\
\text { ini }\end{array}$ & $\begin{array}{l}\text { Narendra memilih untuk } \\
\text { mengambil semua dana } \\
\text { pensiunnya } \\
\text { menyekolahkan Aurora ke luar } \\
\text { negeri. }\end{array}$ \\
\hline
\end{tabular}

Sumber: hasil penelitian 2021

Karakter ayah ditampilkan memberikan perhatian dengan segala upayanya agar anaknya dapat menempuh pendidikan dan sukses dalam kehidupan mereka.

Berikutnya, bentuk cooperative parenting yang secara sederhana diartikan sebagai peran ayah untuk membentuk support system yang baik demi perkembangan anak. Tabel 7 menjelaskan bahwa tidak semua film menampilkan karakter ayah yang menjalankan peran cooperative parenting. Hal ini ditengarai karena sejumlah karakter ayah dalam penelitian ini berstatus single parent sebab pasangannya telah meninggal dunia.

\section{Tabel 7. Bentuk Cooperative parenting di Film Indonesia}

berdasarkan Fathering Indicator Framework

\begin{tabular}{|c|c|c|}
\hline No & Judul Film & Cooperative parenting \\
\hline 1 & $\begin{array}{l}\text { Nagabonar } \\
\text { jadi dua }\end{array}$ & - \\
\hline 2 & $\begin{array}{l}\text { Tampan } \\
\text { Tailor }\end{array}$ & - \\
\hline 3 & Lovely man & $\begin{array}{lrr}\text { Ipuy menghubungi mantan } \\
\text { istrinya untuk memberitahukan } \\
\text { kondisi Cahaya yang datang } \\
\text { menemuinya. } & \text { Sejak dia } \\
\text { meninggalkan } & \text { istri dan }\end{array}$ \\
\hline
\end{tabular}

\begin{tabular}{|c|c|c|}
\hline & & $\begin{array}{l}\text { anaknya, komunikasi terkait } \\
\text { anaknya selalu dilakukannya } \\
\text { selain memberikan nafkah } \\
\text { untuk keperluan sekolah dan } \\
\text { kehidupan keseharian. }\end{array}$ \\
\hline 4 & $\begin{array}{l}\text { Ayah } \\
\text { menyayangi } \\
\text { tanpa akhir }\end{array}$ & - \\
\hline 5 & $\begin{array}{l}\text { Mencari } \\
\text { hilal }\end{array}$ & - \\
\hline 6 & $\begin{array}{l}\text { Sabtu } \\
\text { bersama } \\
\text { Bapak }\end{array}$ & $\begin{array}{l}\text { Gunawan menemani istrinya, } \\
\text { Itje untuk mengasuh kedua } \\
\text { anaknya, Satya dan Cakra } \\
\text { melalui video yang telah } \\
\text { dibuatnya sebelum meninggal. } \\
\text { Melalui video tersebut, } \\
\text { Gunawan bekerjasama dengan } \\
\text { istrinya untuk membesarkan } \\
\text { kedua anaknya. }\end{array}$ \\
\hline 7 & $\begin{array}{l}\text { Cek toko } \\
\text { sebelah }\end{array}$ & - \\
\hline 8 & $\begin{array}{l}\text { Keluarga } \\
\text { Cemara }\end{array}$ & $\begin{array}{lr}\text { Abah senantiasa } & \text { bekerjama } \\
\text { dengan emak untuk mengasuh } \\
\text { kedua anaknya. } & \text { Keduanya } \\
\text { saling membantu } & \text { mengatasi } \\
\text { persoalan yang } & \text { dihadapi } \\
\text { terlebih setelah } & \text { Abah } \\
\text { mengalami kesulitan ekonomi } \\
\text { dan mengharuskan mereka } \\
\text { kembali ke desa. }\end{array}$ \\
\hline 9 & $\begin{array}{l}\text { Orang kaya } \\
\text { baru }\end{array}$ & $\begin{array}{l}\text { Hikmat bekerjasama dengan } \\
\text { istrinya untuk memutuskan } \\
\text { semua hal terkat anak mereka, } \\
\text { misalnya saat anak ketiga } \\
\text { mereka akan melanjutkan ke } \\
\text { sekolah menengah atas, } \\
\text { keduanya berdiskusi untuk } \\
\text { memilih sekolah yang sesuai. }\end{array}$ \\
\hline 10 & $\begin{array}{l}\text { Nanti kita } \\
\text { cerita } \\
\text { tentang hari } \\
\text { ini }\end{array}$ & - \\
\hline
\end{tabular}

Sumber: hasil penelitian 2021

Dari sepuluh film yang diteliti, hanya empat karakter ayah yang bekerjasama dengan pasangannya demi perkembangan anak secara optimal. Terakhir, bentuk father healthy living diartikan sebagai ayah memainkan peran sebagai role model yang baik bagi anaknya. Ayah memberikan contoh baik melalui gaya hidup yang 
sehat, pendidikan yang baik serta perilaku yang sesuai etika dan norma sosial. Dari tabel 8, tampak bahwa tujuh dari sepuluh karakter ayah menjalankan bentuk father healthy living dengan menjadi role model yang baik bagi anaknya.

\section{Tabel 8. Bentuk Father healthy living di Film} Indonesia

berdasarkan Fathering Indicator Framework

\begin{tabular}{|c|c|c|}
\hline No & Judul Film & Father healthy living \\
\hline 1 & $\begin{array}{l}\text { Nagabonar } \\
\text { jadi dua }\end{array}$ & $\begin{array}{l}\text { Nagabonar memberikan contoh } \\
\text { terkait penghormatan pada } \\
\text { leluhur dan nilai adat serta } \\
\text { kesetiaan pada Bonaga } \\
\text { anaknya. }\end{array}$ \\
\hline 2 & $\begin{array}{l}\text { Tampan } \\
\text { Tailor }\end{array}$ & $\begin{array}{l}\text { Topan menjadi role model bagi } \\
\text { Bintang anaknya dengan } \\
\text { memberikan contoh kerja keras } \\
\text { dalam mewujudkan mimpi, } \\
\text { tidak mudah putus asa dan } \\
\text { kesetiaan. }\end{array}$ \\
\hline 3 & Lovely man & - \\
\hline 4 & $\begin{array}{l}\text { Ayah } \\
\text { menyayangi } \\
\text { tanpa akhir }\end{array}$ & $\begin{array}{l}\text { Juna menjadi role model } \\
\text { tentang sosok ayah yang baik } \\
\text { bagi Mada anaknya. }\end{array}$ \\
\hline 5 & $\begin{array}{l}\text { Mencari } \\
\text { hilal }\end{array}$ & - \\
\hline 6 & $\begin{array}{l}\text { Sabtu } \\
\text { bersama } \\
\text { Bapak }\end{array}$ & $\begin{array}{l}\text { Gunawan memberikan contoh } \\
\text { yang baik terkait bagaimana } \\
\text { menjadi seorang laki-laki pada } \\
\text { kedua anaknya. }\end{array}$ \\
\hline 7 & $\begin{array}{l}\text { Cek toko } \\
\text { sebelah }\end{array}$ & $\begin{array}{l}\text { Koh Afuk menjadi role model } \\
\text { tentang nilai kejujuran dan } \\
\text { kesetiaan pada kedua anaknya, } \\
\text { Yohan dan Erwin. }\end{array}$ \\
\hline 8 & $\begin{array}{l}\text { Keluarga } \\
\text { Cemara }\end{array}$ & $\begin{array}{l}\text { Abah berupaya memberikan } \\
\text { semangat dan menanamkan } \\
\text { nilai kebaikan terhadap anak- } \\
\text { anaknya meski dalam kondisi } \\
\text { kehidupan yang sangat } \\
\text { sederhana. Abah senantiasa } \\
\text { menyatakan bahwa harta yang } \\
\text { paling berharga adalah } \\
\text { keluarga. }\end{array}$ \\
\hline 9 & $\begin{array}{l}\text { Orang kaya } \\
\text { baru }\end{array}$ & $\begin{array}{l}\text { Hikmat memberikan } \\
\text { pembelajaran yang sangat } \\
\text { berharga bagi ketiga anaknya } \\
\text { terkait dengan harta dan } \\
\text { kebahagiaan. Bahwa } \\
\text { kebahagiaan tidak ditentukan } \\
\text { oleh banyaknya harta yang kita } \\
\text { miliki }\end{array}$ \\
\hline
\end{tabular}

\begin{tabular}{|l|l|l|}
\hline 10 & $\begin{array}{l}\text { Nanti kita } \\
\text { cerita } \\
\text { tentang hari } \\
\text { ini }\end{array}$ & - \\
\hline
\end{tabular}

Sumber: hasil penelitian 2021

Merujuk pada tabel 8 tampak bahwa karakter ayah dalam sejumlah film tersebut menjadi role model yang baik bagi anaknya.

\section{Fatherhood di Film Indonesia Era 2000-an}

Di bagian akhir ini, akan diuraikan interpretasi bentuk fatherhood yang ditemukan dalam relasi ayah-anak di film Indonesia dikaitkan dengan gender role dalam sistem patriarki. Patriarki adalah struktur dalam masyarakat dimana laki-laki berperan memberi nafkah, sebaliknya perempuan berperan mengurus ranah domestik, termasuk pengasuhan anak. Pada ideologi patriarki, terdapat sejumlah mitos yang melekat pada ayah, diantaranya ayah tidak dibutuhkan anak karena ayah hanya berperan mencari nafkah.

Namun perubahan terjadi karena adanya trend sosial yang terjadi di dunia sejak awal abad ke-21, salah satunya adalah perempuan mulai turut mencari nafkah, sehingga waktu untuk mengurus pekerjaan domestik berkurang. Ibu memerlukan bantuan ayah. Akibatnya, pembatasan peran domestik dan publik antara ayah dan ibu tidak lagi berbatas tegas. Sehingga muncul konsep fatherhood, yang dianggap merupakan bentuk dari maskulinitas baru, yakni maskulinitas yang melibatkan ayah untuk lebih bertanggung jawab pada hal-hal yang terkait dengan mengasuh anak dan pekerjaan rumah tangga.

Penggambaran ayah melalui karakter dalam film Indonesia bertema fatherhood era 2000-an secara garis besar menunjukkan wacana 
Jurnal PIKMA: Publikasi Media Dan Cinema, Volume 4, No. 1, September 2021, hlm 56-71

pencerahan dengan berupaya mematahkan sejumlah mitos patriarki yang selama ini berkembang di masyarakat. Pertama, terkait dengan mitos bahwa ayah secara emosional jauh dengan anak. Karena sifat sensitif dan ekspresif dalam mengungkap perasaan dianggap termasuk sisi feminin. Kenyataannya di sejumlah film dalam penelitian ini, justru ditampilkan sosok ayah lebih sensitif, ekspresif, memiliki hubungan yang lebih emosional dengan anak mereka, tanpa harus kehilangan sisi maskulinitas mereka. Seperti yang tampak di film "Nagabonar jadi 2", "Tampan Tailor”, "Lovely Man”, “Ayah Menyayangi Tanpa Akhir", "Keluarga Cemara", "Cek Toko Sebelah", "Keluarga Cemara" dan "Nanti Kita Cerita Tentang Hari Ini” (NKCTHI).

Kedua, mitos yang menyatakan bahwa peran ayah hanya terbatas pada ranah publik. Mitos ini utamanya terkait dengan peran ayah sebagai pencari nafkah utama dalam keluarga. Hal ini sesuai dengan pandangan tradisional patriarki. Dalam keseluruhan film Indonesia yang diteliti kali ini, peran ayah sebagai pencari nafkah tetap ditampilkan. Namun demikian, selain tetap menjalankan peran sebagai pencari nafkah, dibeberapa film, digambarkan ayah juga berperan di ranah domestik. Ayah hadir dalam kehidupan keseharian anak, terlibat dengan masalah akademik mereka, menemani mereka ketika mendapat masalah, menjadi contoh yang baik bagi anak. Misalnya di film "Keluarga Cemara", "Ayah Menyayangi Tanpa Akhir", "Sabtu Bersama Bapak" dan "Nanti Kita Cerita Tentang Hari Ini" (NKCTHI).
Ketiga, terkait dengan mitos maskunilitas yang melekat pada ayah, menyebabkan pengasuhan anak termasuk dalam sifat feminin. Artinya pengasuhan anak menjadi tugas seorang ibu. Namun dalam sejumlah film dalam penelitian ini, justru mematahkan mitos tersebut. Hal ini tampak terutama pada film yang menampilkan ayah sebagai single parent, misalnya di film "Nagabonar jadi 2", "Tampan Tailor", “Ayah Menyayangi Tanpa Akhir”. Karakter Nagabonar, Topan dan Juna sebagai ayah dalam film-film tersebut bahkan menjalankan peran ibu untuk merawat anak semenjak kecil, karena pasangan meninggal dunia saat anak baru dilahirkan ataupun masih sangat kecil usianya.

Namun demikian, terdapat sejumlah mitos patriarki yang masih tetap dipertahankan dan ditampilkan dalam sejumlah scene relasi ayah dan anak. Misal yang tampak dalam penggambaran karakter Nagabonar, Mahmud, Koh Afuk. Mitos tersebut antara lain terkait pembagian peran lakilaki perempuan, perbedaan ranah publik dan domestik serta kecenderungan sifat maskulin dan feminin. Hal ini ditengarai dipengaruhi konteks etnis dan agama yang melatarbelakangi sosok ayah. Seorang ayah mendapat sosialisasi nilai patriarki yang diajarkan dalam keluarga besarnya selama ini, dan sudah dilakukan secara turun temurun sehingga dianggap alamiah.

Tidak dapat dipungkiri latar belakang konteks sosio kultural mempengaruhi perilaku ayah dalam hal pengasuhan anak. Termasuk adanya pengaruh trend sosial dunia, salah satunya yang utama terkait angkatan kerja kalangan perempuan. Apabila relasi 
ibu dengan anak terjadi didasarkan karena dasar biologis, maka relasi ayah dengan anak bisa jadi terbentuk karena gerakan evolusioner, seperti feminisme, gerakan fatherhood yang mendukung adanya pembagian peran yang seimbang, saling mendukung dan keterlibatan ayah dan ibu dalam pengasuhan anak.

\section{KESIMPULAN}

Film Indonesia era 2000-an menggambarkan fatherhood melalui karakter ayah sebagai sosok yang tidak hanya berperan sebagai pemberi nafkah, namun juga berperan sebagai supportive dan cooperative caregiver, role model yang baik, termasuk menjadi bagian integral urusan domestik. Temuan penelitian ini juga mengkonfirmasi bahwa konteks sosio kultural dan trend sosial di dunia melatarbelakangi pergesaran Penggambaran fatherhood di Indonesia.

Sejumlah temuan menarik yang diperoleh diantaranya, pertama, perubahan sosial ekonomi seorang ibu, menyebabkan ayah berperan melengkapi bahkan mengantikan peran yang tidak dilakukan ibu secara maksimal dalam pengasuhan anak dan ranah domestik.

Kedua, sejumlah mitos patriarki yang coba dipatahkan dalam film Indonesia bertema fatherhood misalnya dalam relasi ayah dan anak, sosok ayah diperlihatkan lebih sensitif, ekspresif, memiliki hubungan yang lebih emosional. Di samping itu, batasan peran ayah ditampilkan tidak hanya diranah publik, tapi juga diranah domestik. Begitu pula dengan konsep maskulin yang coba dipatahkan dengan menampilkan Penggambaran ayah yang mengasuh anak sejak lahir.

Ketiga, sebaliknya, masih tetap ada sejumah mitos patriarki yang dipertahankan dalam beberapa karakter ayah dengan latar belakang sosio kultural beragam tersebut. Misalnya pembagian peran laki-laki dan perempuan, perbedaan ranah publik dan domestik serta sifat maskulin dan feminin. Mitos tersebut masih dipertahankan karena sosialisasi nilai patriarki yang diajarkan dalam keluarga selama ini dilakukan secara turun temurun hingga dianggap alamiah.

Konteks sosio kultural beragam yang ditampilkan dalam film Indonesia membuka banyak peluang penelitian lanjutan yang dapat dilakukan. Penelitian berikutnya, dapat mengeksplorasi lebih lanjut pengaruh konteks sosiokultural, seperti halnya etnis, agama, gender anak terhadap bentuk fatherhood, baik dengan metode analisis resepsi maupun analisis semiotika.

\section{DAFTAR PUSTAKA}

Adams, M. Walker C, and O'Conell, P. (2011). Invisible or Involved Fathers? A Content Analysis of Representation of Parenting in Young Children's Picture books in The UK, Sex Roles, 65(3-4), 259-270. Retrieved October 28, 2014, from DOI :10.1007/s11199-011-0011-8.

Assarsson,L. Aarsand, P. (2011). How to be good: Media Representation of Parenting. Studies in the Education of Adults, 43, 78-92

Cabrera, Natasha J, Chaterine S, Tamis-LeMonda, Robert H Bardley, Sandra Hoffert, Michael E. Lamb. (2000). Fatherhood in the Twenty-First Century. Child Development (January/February) vol. 71 number 1,The Society for Research in Child Development Inc :127-136. 
Denzin, Norman K. (2017). Handbook of Qualitative Research, $5^{\text {th }}$ Edition. London: Sage Publication.

Evans, John R. (2015). Defining Dad : Media Depiction of The Modern Father in Print Advertising. Tesis. Stevenson University.

Gadsden Vivian ; Fagan Jay, Ray Aisha, Davis James Earl. (2011). Fathering Indicators Framework : A Tool for Quantitative and Qualitative Analysis. Pennsylvania University, Philadelphia. National Center on Fathers and Families.

Gurova, Ercan. (2016). Modern Fatherhood in Films. $1^{\text {st }}$ International Research Congress Humanity and Social Science, Madrid.

Habib, C. (2012). The Transition to fatherhood : A literature review exploring paternal involvement with identity theory. Journal of Families Studies, 18, 103-120

Hardianto, Nikita. (2015). Analisis Isi Konten Fathering dalam Film Animasi Disney tahun 2000-2013. Skripsi. Universitas Kristen Petra Surabaya.

Ivy Chelsea, Jove Rose. (2010). The Portrayal of Men in The Media. Undergraduate Research Journal for The Human Sciences. Vol. 9

Jensen, Lene Arnett. (2015). The Oxford Handbook of Human Development and Culture : An Interdisciplinary Perspective. New York : Oxford University Press.

Jpnn.com (2021). Menyedihkan ! Indonesia Urutan Ketiga di Dunia Negara Tanpa Ayah. Retrieved March 31, 2021 from https://www.jpnn.com/news/menyedihkanindonesia-urutan-ketiga-di-dunia-negaratanpa-ayah.

Kemenpppa.go.id. (2020). Perkuat Peran Ayah untuk Meningkatkan Kualitas Pengasuhan Anak. Retrieved September 10, 2020 from https://www.kemenpppa.go.id/index.php/page/ $\mathrm{read} / 29 / 2860 /$ perkuat-peran-ayah-untukmeningkatkan-kualitas-pengasuhan-anak.

Kompas.com. (2008). 10 Mitos tentang Ayah. Retrieved May 12, 2008 from https://nasional.kompas.com/read/2008/12/05/ 12290732/10-mitos-tentang-ayah.

Diunduh pada 2 Juli 2021 pukul 10.00 wib.

Manika, Elly. (2016). Representasi Fatherhood dalam Majalah Ayahbunda, Skripsi. Universitas Diponegoro Semarang.

Maiter Sarah, Miller Wayne Ambrose (2008). Fatherhood and Culture : Moving Beyond Stereotypical Understanding, Journal of Ethics and Cultural Diversity in Social Work, 17 (3):279-300.

Patton, Michael Quinn. (2014). Qualitative Research \& Evaluation Methods. London: Sage Publication.

Ramadhani Yulaika. (2019). Sejarah Hari Ayah Nasional yang Diperingati Setiap 12 November. Retrieved November 12, 2019 from https://tirto.id/sejarah-hari-ayah-nasionalyang-diperingati-setiap-12-november-elwt.

Schmitz. Rachel M. (2016). Constructing Men as Fathers : A Content Analysis of Formulations of Fatherhood in Parenting Magazines. https//doi.org/10.1177/1060826515624381

Schreier, Margrit. (2012). Qualitative Content Analysis in Practice. London: Sage Publication. 